This is the final peer-reviewed accepted manuscript of:

DI GIROLAMO, GIUSEPPE; GRIGATTI, MARCO; BERTIN, LORENZO; CIAVATTA, CLAUDIO; BARBANTI, LORENZO

Enhanced substrate degradation and methane yield with maleic acid pre-treatments in biomass crops and residues

which has been published in final form in BIOMASS \& BIOENERGY 2016 54:2 182-190.

The final published version is available online at: http://dx.doi.org/10.1016/j.biombioe.2015.12.029

(c) 2017 Elsevier. This manuscript version is made available under the Creative Commons Attribution-NonCommercial-NoDerivs

(CC BY-NC-ND) 4.0 International License (http://creativecommons.org/licenses/by-nc-nd/4.0/)

Research paper

\title{
Enhanced substrate degradation and methane yield with maleic acid pre-treatments in biomass crops and residues
}

\author{
Giuseppe Di Girolamo a, Marco Grigatti a, Lorenzo Bertin ${ }^{\text {b }}$, Claudio Ciavatta a, \\ Lorenzo Barbanti ${ }^{\text {a, * }}$ \\ ${ }^{a}$ Department of Agricultural Sciences, University of Bologna, Viale Fanìn 44, 40127 Bologna, Italy \\ b Department of Civil, Environmental, and Materials Engineering, University of Bologna, Via Terracini 28, 40131 Bologna, Italy
}

\section{A R T I C L E I N F O}

Article history:

Received 3 November 2015

Received in revised form

22 December 2015

Accepted 22 December 2015

Available online $\mathrm{xxx}$

Keywords:

Maleic acid

Ligno-cellulosic biomass

Anaerobic digestion

FTIR analysis

Methane

\begin{abstract}
A B S T R A C T
Organic acids are envisaged as alternative catalysts to strong mineral acids, in pre-treatment of lignocellulosic biomass for anaerobic digestion (AD). To evaluate this hypothesis, an untreated control and four pre-treatments $\left(25^{\circ} \mathrm{C}\right.$ for $24 \mathrm{~h}$ ) involving two levels of maleic acid ( 34.8 and $69.6 \mathrm{~kg} \mathrm{~m}^{-3}$ ), alone and combined with sulphuric acid $\left(4 \mathrm{~kg} \mathrm{~m}^{-3}\right)$, were studied in three agricultural substrates: Arundo (aka giant reed), Barley straw and B133 fibre sorghum. Methane production was assessed in a batch AD assay ( $35{ }^{\circ} \mathrm{C}$ for 51 days) with $4 \mathrm{~g} \mathrm{~L}^{-1}$ of volatile solid (VS) load. Fibre composition and structure were investigated through chemical analysis and Fourier transform infrared (FTIR) spectrometry. Arundo and B133 that were the most and least recalcitrant substrate, respectively, staged the highest and lowest increase in methane with high maleic acid: $+62 \%$ over $218 \mathrm{~cm}^{3} \mathrm{~g}^{-1}$ of VS in untreated Arundo; $+36 \%$ over $284 \mathrm{~cm}^{3} \mathrm{~g}^{-1}$ of VS in untreated B133. Barley straw showed an intermediate behaviour $(+41 \%$ over $269 \mathrm{~cm}^{3} \mathrm{~g}^{-1}$ of VS). $\mathrm{H}_{2} \mathrm{SO}_{4}$ addition to maleic acid did not improve $\mathrm{CH}_{4}$ output. The large increase in methane yield determined by pre-treatments was reflected in the concurrent decrease of fibre (between 14 and $39 \%$ depending on fibrous component). Based on FTIR spectra, bands assigned to hemicellulose and cellulose displayed lower absorbance after pre-treatment, supporting the hypothesis of solubilisation of structural carbohydrates and change in fibre structure. Hence, maleic acid was shown a suitable catalyst to improve biodegradability of ligno-cellulosic biomass, especially in recalcitrant substrates as Arundo.
\end{abstract}

\section{Introduction}

Ligno-cellulosic biomass of agricultural origin (i.e. energy crops and residues) is one of the key options for meeting the world's energy demand [1], while at the same time minimizing competition with food crops [2]. Anaerobic digestion (AD) is widely used at present for the energy conversion of agricultural biomasses.

These substrates are composed of the three fibre fractions (cellulose, hemicellulose and lignin) in a proportion and relationship that varies according to plant species. Among these fractions, lignin is fairly resistant to $\mathrm{AD}$, retarding or preventing the

Abbreviations: AD, anaerobic digestion; AIL, acid insoluble lignin; Cell, cellulose; FTIR, Fourier transform infrared spectrometry; H-cell, hemicellulose; LSD, least significant difference; TS, total solids; VS, volatile solids.

* Corresponding author.

E-mail address: lorenzo.barbanti@unibo.it (L. Barbanti). hydrolysis of carbohydrates [3]. Therefore, during AD of lignocellulosic substrates, hydrolysis is considered the rate limiting step [4], influencing kinetics and, consequently, production of biogas. To overcome the recalcitrance of ligno-cellulosic substrates, pre-treatments are devised to loosen fibre structure, remove or rearrange lignin and hydrolyze cellulose and hemicellulose [5], resulting in faster hydrolysis and improved methane yield.

Pre-treatments rely on physical, chemical and biological means, sometimes combined [5]. Among them, chemical pre-treatments with the use of dilute sulphuric acid have been widely investigated [5-9], performing satisfactory results. The main reactions occurring during dilute sulphuric acid pre-treatment are the hydrolysis of hemicellulose [10], a partial hydrolysis of cellulose and a solubilisation of lignin, leading to changes in biomass structure [11]. The main drawbacks from the use of sulphuric acid are: i) corrosion of the equipment during $\mathrm{AD}$, and ii) production of $\mathrm{SO}_{4}^{2-}$ boosting the activity of sulphate-reducing bacteria, which are 
known to negative affect the incubation [12]. To avoid these constraints, the use of organic instead of mineral acids could be envisaged in the frame of a biomimetic approach, i.e. one that mimics natural enzymes. This is based on the fact that enzymes catalysing cellulose and hemicellulose hydrolysis act through a general acid-base mechanism by means of two carboxylic acids in the enzyme active site [13]. Accordingly, dicarboxylic acids having a similar catalytic structure as enzymes, were proposed as biomimetic catalysts [14], and they were shown to be actually more selective for $\beta-(1,4)$-glycolic bonds than sulphuric acid [13]. Maleic acid was shown the most favourable dicarboxylic acid as it concerns catalysis selectivity [15]. However, even if maleic acid is easier to handle than sulphuric acid due to its lower strength, this approach appears more expensive compared to sulphuric acid. For that reason Guo et al. [14] suggested a combination of mineral and organic acid as that fetching higher biomimetic catalysis while, at the same time, reducing the cost for organic acids with a cheaper mineral acid.

With this premise, a vast literature studied the biomimetic approach to enhance hemicellulose hydrolysis and cellulose access for enzymatic attack, in view of higher bioethanol output [8,14,16-18]. Conversely, only a study addressed methane potential [11]. Therefore, the objective of this work was to investigate bland pre-treatments with organic acid (maleic acid) and the combination of mineral and organic acid (sulphuric + maleic acid) on three ligno-cellulosic substrates of agricultural origin. The effects of pretreatments were evaluated on fibre composition, structure and methane yield compared to untreated substrates.

\section{Material and methods}

\subsection{Investigated substrates}

The three substrates, also used in a previous study on alkaline pre-treatments [19], were: Arundo donax L. (Arundo), a wild type sourced locally ( $44^{\circ} 33^{\prime} \mathrm{N}, 11^{\circ} 21^{\prime} \mathrm{E}$; $32 \mathrm{~m}$ above sea level); B133 fibre sorghum [Sorghum bicolor (L.) Moench], a hybrid from Syngenta Seeds (Casalmorano, CR, Italy); Barley (Hordeum vulgare L.) straw, cv. Ketos from Limagrain (Busseto, PR, Italy). Biomass samples of the two crops and the crop residue were collected from fields at the experimental farm of the University of Bologna in Cadriano (same coordinates as above), Italy, during the year 2010. The soil is a deep alluvial loam, while climate falls in the Mediterranean North environmental zone [20]. Further detail on crop husbandry is given in the above referred work [19]. Arundo was harvested at initial senescence (October 5, 2010), while B 133 sorghum was harvested at hard dough stage (October 18, 2010). Barley straw was collected after combine harvesting of the dry grain, in summer 2010. Biomass samples of the three substrates were oven dried $\left(60^{\circ} \mathrm{C}\right)$ and ground at $2 \mathrm{~mm}$ for chemical characterization, pre-treatments and AD.

\subsection{Acid pre-treatments}

Pre-treatments were carried out with four combinations of organic and mineral acids: maleic acid at low and high concentration (34.8 and $69.6 \mathrm{~kg} \mathrm{~m}^{-3}$ ), alone and combined with sulphuric acid at $4 \mathrm{~kg} \mathrm{~m}^{-3}$ (Table 1). Sulphuric acid concentration was based on a previous assay conducted on the same three substrates.

Pre-treatment procedure and subsequent assessments are summarized in Fig. 1.

Pre-treatment was carried out in the dark at $25{ }^{\circ} \mathrm{C}$ for $24 \mathrm{~h}$, during which time substrates previously dried $\left(60{ }^{\circ} \mathrm{C}\right)$ and ground ( $2 \mathrm{~mm}$ ) were supplemented with the acid solutions and stirred $(10,000 \mathrm{RCF})$. Substrate amounts were set to maintain a
Table 1

Pre-treatment conditions. $\mathrm{O}$ and $\mathrm{M}$ mean organic (maleic) and mineral (sulphuric) acid (Ac.), respectively; $\mathrm{L}$ and $\mathrm{H}$ indicate low and high concentration of maleic acid respectively. Pre-treatments were conducted at $25^{\circ} \mathrm{C}$ for $24 \mathrm{~h}$.

\begin{tabular}{lll}
\hline Pre-treatment & Maleic acid & Sulphuric acid \\
\cline { 2 - 3 } & $\mathrm{Kg} \mathrm{m}^{-3}$ & \\
\hline Untreated & - & - \\
OAc.L & 34.8 & - \\
OAc.H & 69.6 & - \\
M+OAc.L & 34.8 & 4 \\
M+OAc.H & 69.6 & 4 \\
\hline
\end{tabular}

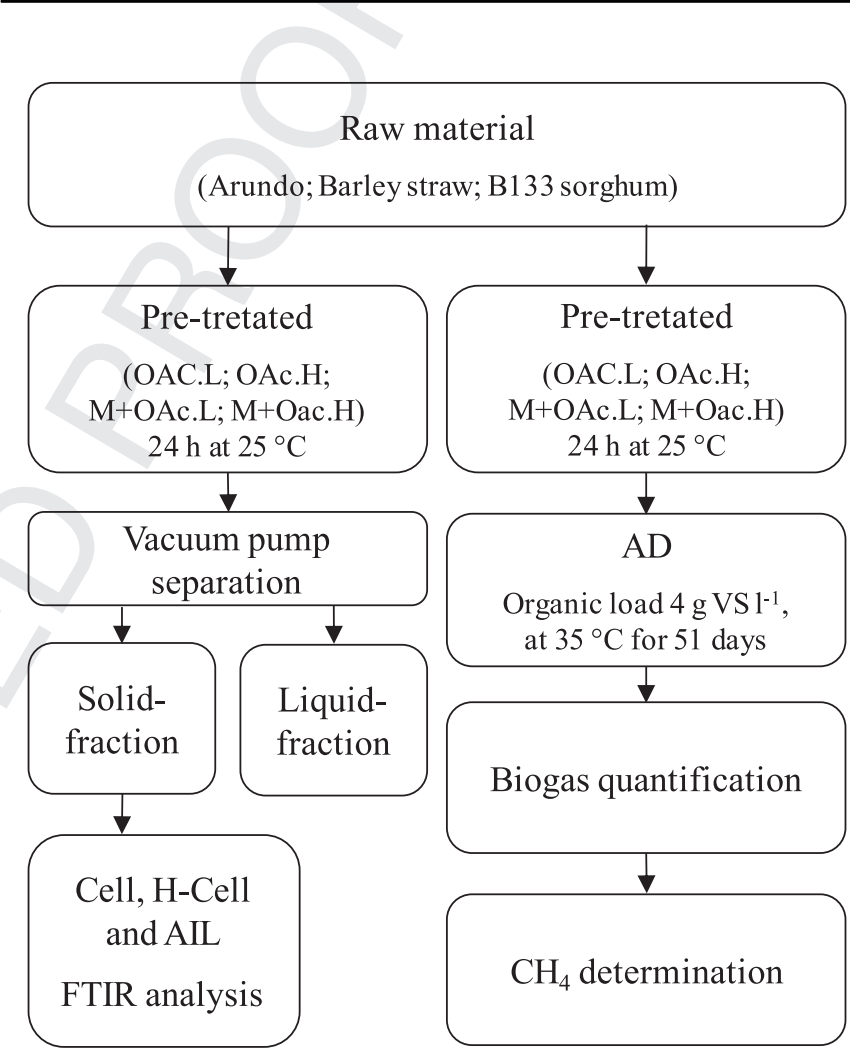

Fig. 1. Scheme of pre-treatment procedure and subsequent assessments. OAc., organic (maleic) acid; $\mathrm{M}+\mathrm{OAc}$., mineral $\left(4 \mathrm{~kg}\right.$ of $\mathrm{H}_{2} \mathrm{SO}_{4} \mathrm{~m}^{-3}$ ) and organic acid; $\mathrm{L}$ and $\mathrm{H}$ mean low $\left(34.8 \mathrm{~kg} \mathrm{~m}^{-3}\right)$ and high $\left(69.6 \mathrm{~kg} \mathrm{~m}^{-3}\right)$ level of maleic acid, respectively. Cell, cellulose; H-cell, hemicellulose; AIL, acid insoluble lignin; FTIR, Fourier transform infrared spectrometry; $\mathrm{AD}$, anaerobic digestion; VS, volatile solids.

concentration of $100 \mathrm{~mL}$ of acid solution $\mathrm{kg}^{-1}$ of total solids (TS). At the end of the process, the liquid fraction was separated by vacuum pump equipped with a Whatman GF/C, Ø $47 \mathrm{~mm}$ filter, while the solid fraction was washed and dried $\left(60{ }^{\circ} \mathrm{C}\right.$ for $48 \mathrm{~h}$ ) prior to chemical analysis (Fig. 1).

In parallel to this, the same pre-treatments were carried out on the three substrates in view of AD (Fig. 1).

\subsection{Anaerobic digestion}

A batch AD assay was carried out using the same basic procedure described in Ref. [19]. Briefly, the inoculum was retrieved from the same source, and was subjected to the same period of adaptation. At the end, it showed the following data: TS, $32 \mathrm{mg} \mathrm{g}^{-1}$;

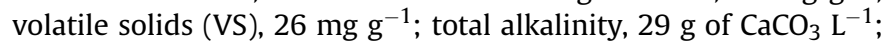
$\mathrm{pH}, 7.8$.

The rest of the procedure was the same as in Refs. [19], namely as it concerns incubation temperature $\left(35^{\circ} \mathrm{C}\right)$, organic load $(4 \mathrm{~g}$ of 
Table 2

Bands of absorbance in FTIR spectra referred to functional groups assigned to fibre fractions.

\begin{tabular}{|c|c|c|c|}
\hline Wavenumber $\left(\mathrm{cm}^{-1}\right)$ & Group & Fraction & Literary reference \\
\hline 2900 & $\mathrm{C}-\mathrm{H}$ stretching & Cell & [23] \\
\hline 1720 & $\mathrm{C}=\mathrm{O}$ stretching acetyl or carboxylic acid & $\mathrm{H}$-cell and lignin & {$[24,25]$} \\
\hline 1430 & $-\mathrm{CH}_{2}$ bending & Cell & [26] \\
\hline 1375 & $\mathrm{C}-\mathrm{H}$ deformation & Cell & [27] \\
\hline 1315 & $-\mathrm{CH}_{2}$ wagging vibrations & Cell and H-cell & [25] \\
\hline 1158 & $\mathrm{C}-\mathrm{O}-\mathrm{C}$ stretching & Cell and H-cell & [25] \\
\hline 898 & Glucose ring stretch, $\mathrm{C}-\mathrm{H}$ deformation & Cell & [28] \\
\hline
\end{tabular}

Cell, cellulose; H-cell, hemicellulose.

$\left.\mathrm{VS} \mathrm{L}^{-1}\right)$, and the relatively high inoculum to substrate ratio (5.2:1, VS:VS) that was chosen to offset inhibiting factors [21,22]. The following six controls were added: blank (inoculum alone); blank plus the four combinations of maleic and sulphuric acid; glucose at

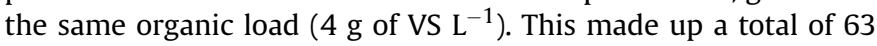
serum bottles under simultaneous incubation.

\subsection{Analytical methods}

\subsubsection{Chemical analyses}

Chemical determinations on untreated substrates were the same as in the cited work involving the same samples [19]: TS, VS, total Kjeldahl nitrogen, protein, lipids, starch, extractives, hemicellulose (H-cell) and cellulose (Cell), and acid insoluble lignin (AIL). The same data are, therefore, used in this work. Further detail on analytical methods is given in Ref. [19].

\subsubsection{Biogas measurement and analysis}

Eleven times during the incubation (day 2, 4, 6, 9, 12, 16, 19, 25, 31, 41 and 51), biogas amount and composition were assessed with the same procedure and equipment described in Ref. [19]. Methane production from the controls described in Section 2.3 were subtracted from methane produced from the respective substrates. Subsequent calculations [19] allowed us to express the amount of methane $\left(\mathrm{cm}^{3} \mathrm{~g}^{-1}\right.$ of $\left.\mathrm{VS}\right)$ produced during the incubation.

\subsubsection{FTIR analysis}

The structure of the solid fraction of untreated and pre-treated substrates was analysed with Fourier transform infrared (FTIR) spectrometry, using the same instrumentation, software and procedure as in Ref. [19]. Seven characteristic bands of absorbance (Table 2) were retained for subsequent discussion.

Thereafter, the total crystallinity index (TCI) and the lateral order index (LOI) were calculated as the respective 1375 to 2900 and 1430 to $898 \mathrm{~cm}^{-1}$ peak ratio [26,27]. TCI and LOI express functional relationships in Cell fractions.

\subsection{Data analysis}

Data of chemical analysis were subjected to one-way ANOVA for

Table 3

Compositional analysis of untreated substrates.

\begin{tabular}{|c|c|c|c|c|c|c|c|c|c|}
\hline \multirow[t]{2}{*}{ Substrate } & \multirow[t]{2}{*}{ VS $\mathrm{mg} \mathrm{g}^{-1}$ of TS } & \multirow[t]{2}{*}{$\mathrm{C}: \mathrm{N}$} & Extr. & Protein & Lipids & Starch & Cell & H-cell & AIL \\
\hline & & & \multicolumn{7}{|c|}{$\mathrm{mg} \mathrm{g}^{-1}$ of VS } \\
\hline Arundo & $926 \mathrm{~b}$ & $56.9 \mathrm{~b}$ & $211 b$ & 51.2 & $9.5 \mathrm{c}$ & $38.5 \mathrm{~b}$ & $322 \mathrm{a}$ & $205 \mathrm{~b}$ & $229 a$ \\
\hline Barley straw & $924 \mathrm{c}$ & $64.1 \mathrm{a}$ & $221 \mathrm{~b}$ & 44.4 & $12.2 \mathrm{~b}$ & $16.2 \mathrm{c}$ & $317 \mathrm{a}$ & $214 \mathrm{a}$ & $215 \mathrm{ab}$ \\
\hline B133 sorghum & $949 a$ & $54.2 \mathrm{~b}$ & 349 a & 52.2 & $16.3 \mathrm{a}$ & $53.3 \mathrm{a}$ & $228 \mathrm{~b}$ & $126 \mathrm{c}$ & $198 \mathrm{~b}$ \\
\hline
\end{tabular}

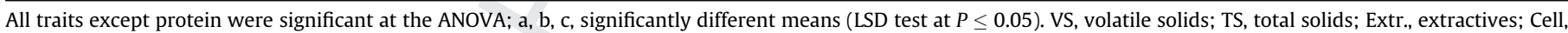
cellulose; H-cell, hemicellulose; AIL, acid insoluble lignin.

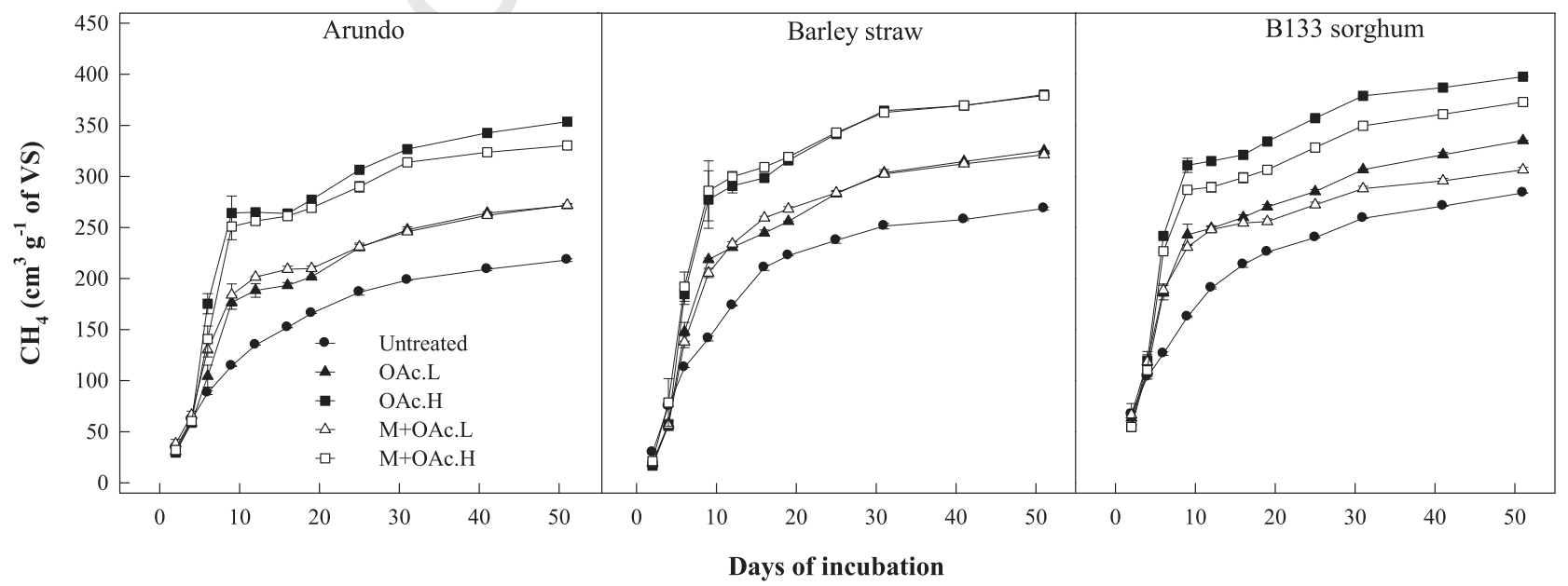

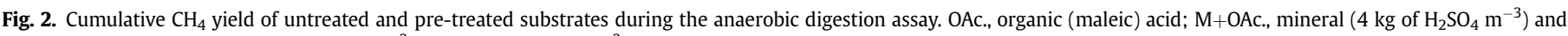
organic acid; $\mathrm{L}$ and $\mathrm{H}$ mean low $\left(34.8 \mathrm{~kg} \mathrm{~m}^{-3}\right)$ and high $\left(69.6 \mathrm{~kg} \mathrm{~m}^{-3}\right)$ level of maleic acid, respectively. Vertical bars, \pm standard deviation. 


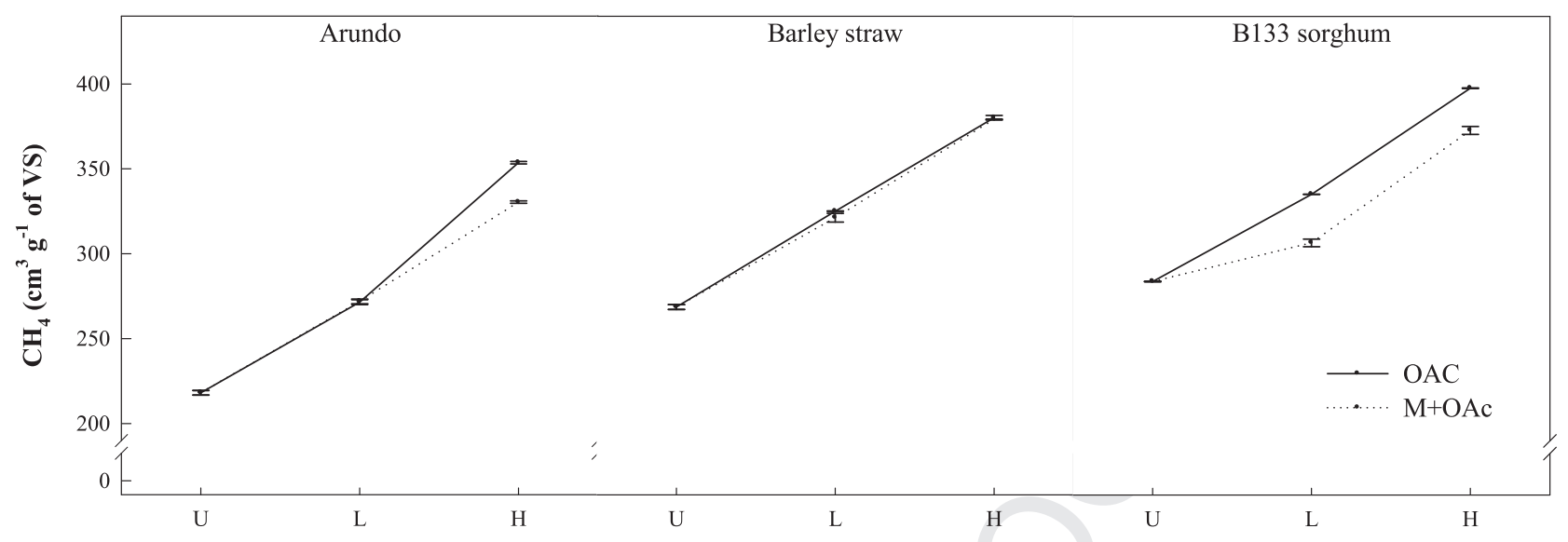

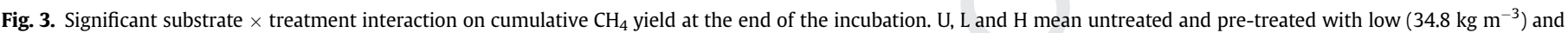

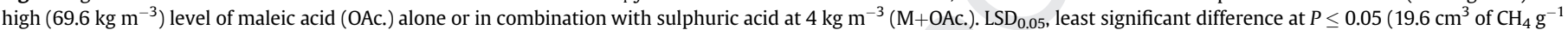
of VS). Vertical bars, \pm standard deviation.

the substrates factor. Data of cumulative $\mathrm{CH}_{4}$ yield were subjected to two-way ANOVA addressing substrates, pre-treatments and their interaction. Fisher's least significant difference (LSD) at $P \leq 0.05$ was used to separate data of significant ANOVA sources.

\section{Results and discussion}

\subsection{Compositional analysis of untreated substrates}

Untreated substrates showed the characteristics reported in Table 3.

VS exhibited a limited variation (from 924 to $949 \mathrm{mg} \mathrm{g}^{-1}$ of TS). The C:N mass ratio ranged between 54 (B133 sorghum) and 64 (Barley straw), which is above the limit (30) indicated for optimum $\mathrm{AD}$ conditions [28]. The extractives were an approximate $200 \mathrm{mg} \mathrm{g}^{-1}$ of VS in Arundo and Barley straw; a much higher amount ( $350 \mathrm{mg} \mathrm{g}^{-1}$ of VS) in B133 sorghum. Barley straw had a mildly lower protein content than the averaged Arundo and B133 sorghum (ca. 45 vs. $52 \mathrm{mg} \mathrm{g}^{-1}$ of VS), associated with a much lower starch content $\left(16.2,38.5\right.$ and $53.3 \mathrm{mg} \mathrm{g}^{-1}$ of VS in the three respective substrates). B133 sorghum evidenced a lower amount of Cell (228 $\mathrm{mg} \mathrm{g}^{-1}$ of VS) and H-cell (126 $\mathrm{mg} \mathrm{g}^{-1}$ of VS) than the averaged Arundo and Barley straw (319 and $210 \mathrm{mg} \mathrm{g}^{-1}$ of VS for the two respective carbohydrates). The sum of the two structural carbohydrates amounted to an approximate 570, 580 and $380 \mathrm{mg} \mathrm{g}^{-1}$ of VS in Arundo, Barley straw and B133 sorghum, respectively. AIL staged a narrow range between 198 and $229 \mathrm{mg} \mathrm{g}^{-1}$ of VS in the respective B133 sorghum and Arundo. Similar structural carbohydrates and lignin content were found by Scordia et al. [17] in Arundo harvested in a wild area, while Sambusiti et al. [29] had found a higher content of lignin (+20\%) in the same sorghum hybrid (B133).

\subsection{Methane yield during the incubation}

The time trend of cumulative $\mathrm{CH}_{4}$ yield is depicted in Fig. 2. In the first 4 days of incubation, $\mathrm{CH}_{4}$ yield was similar in all substrates. Thereafter, pre-treated substrates exhibited a steep increase of $\mathrm{CH}_{4}$ output, followed by a slowdown between ten and twenty days, and by subsequent resumption of the kinetics. Untreated substrates outlined a steady methanation rate (Fig. 2). At 10 days, ca. $50 \%$ of cumulative $\mathrm{CH}_{4}$ yield was produced in the average of the three untreated substrates, vs. $68 \%$ in substrates pre-treated with OAc.L and $\mathrm{M}+\mathrm{OAc} . \mathrm{L}$, and $76 \%$ with OAc.H and $\mathrm{M}+\mathrm{OAc} . \mathrm{H}$ (Fig. 2).

Enhanced $\mathrm{CH}_{4}$ production in pre-treated substrates at the beginning of incubation might be due to conversion of easily degradable compounds, indicating an increase of the overall biodegradability after pre-treatment. This is in agreement with Lee

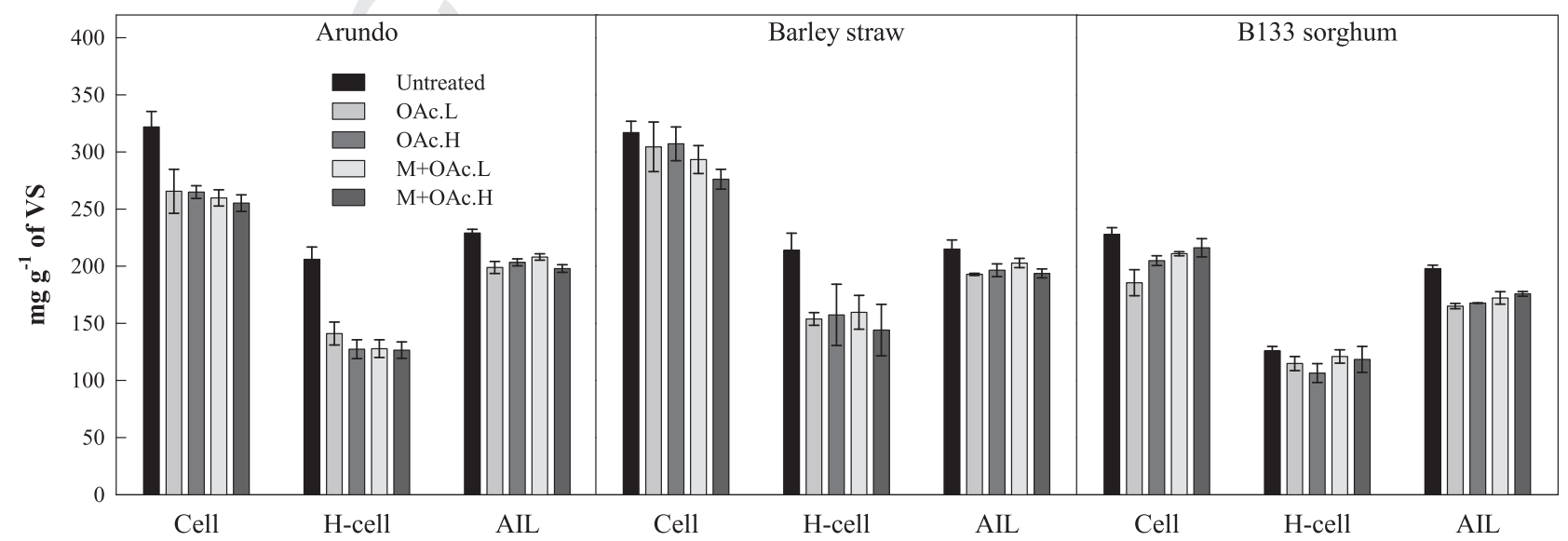

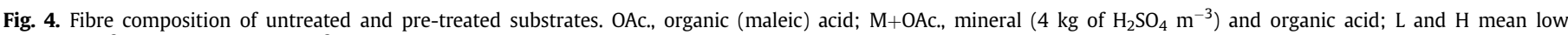
$\left(34.8 \mathrm{~kg} \mathrm{~m}^{-3}\right)$ and high $\left(69.6 \mathrm{~kg} \mathrm{~m}^{-3}\right)$ level of maleic acid, respectively. Cell, cellulose; H-cell, hemicellulose; AIL, lignin. Vertical bars, \pm standard deviation. 


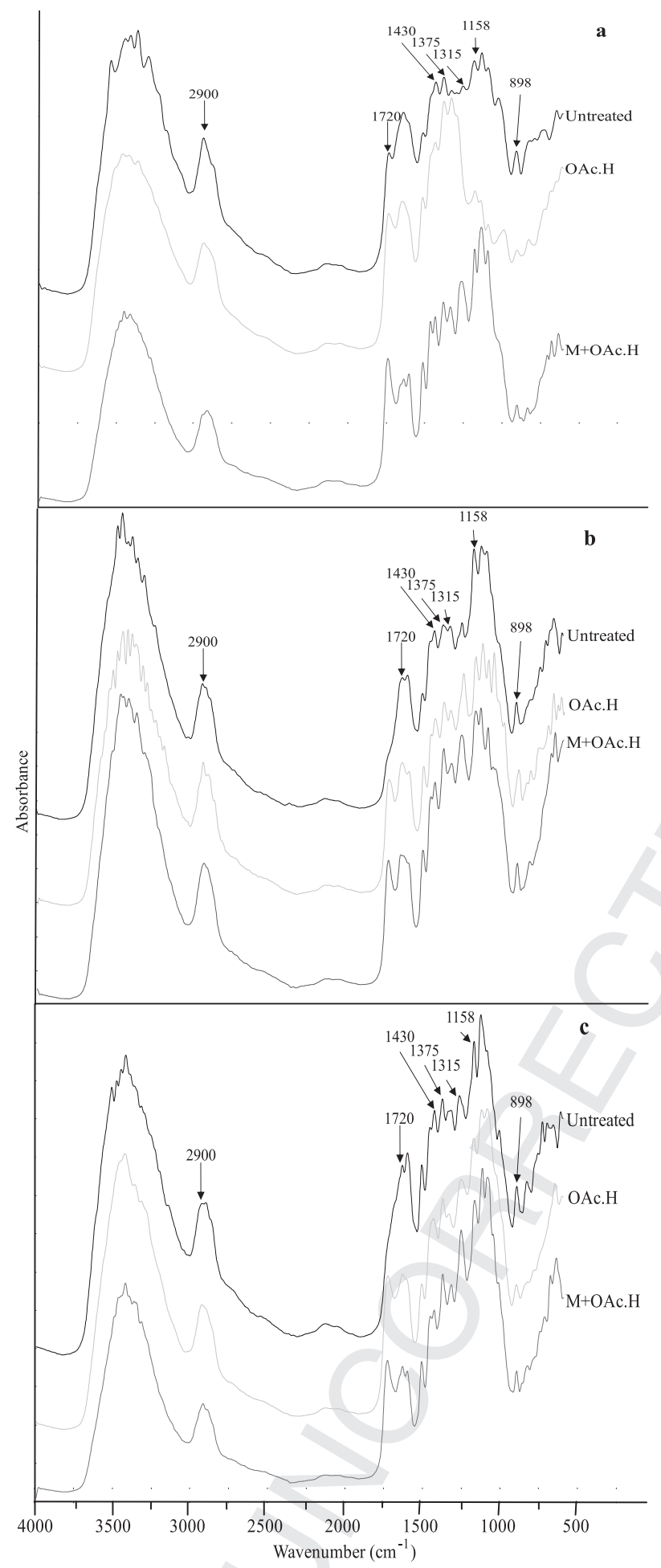

Fig. 5. Fingerprint range from 4000 to $600 \mathrm{~cm}^{-1}$ of the FITR spectra of Untreated (black line), OAc.H (gray line) and M+OAc.H (dark gray) pre-treated Arundo (a), Barley straw (b) and B133 sorghum (c). OAc.H, organic (maleic) acid at high leve $\left(69.6 \mathrm{~kg} \mathrm{~m}^{-3}\right)$; $\mathrm{M}+\mathrm{OAc}$., mineral $\left(4 \mathrm{~kg}\right.$ of $\mathrm{H}_{2} \mathrm{SO}_{4} \mathrm{~m}^{-3}$ ) and organic acid at high level.

and Jeffries [8], who reported that pre-treatment with the same dicarboxylic acid of our experiment (maleic acid) released a remarkable amount of monomeric sugars derived from structural carbohydrates (H-cell and Cell). Conversely, the temporary slowdown of $\mathrm{CH}_{4}$ production observed between 10 and 20 days was likely due to a need of microbial adaptation before tackling the residual, more recalcitrant fraction.

In each substrate, cumulative $\mathrm{CH}_{4}$ yield diverged progressively between untreated and pre-treated samples. Resulting from this, the substrate $\times$ treatment interaction was statistically significant at the end of the incubation, meaning that pre-treatments exerted a different effect on final $\mathrm{CH}_{4}$ output depending on each specific substrate (Fig. 3).

In untreated substrates, Arundo showed a lower $\mathrm{CH}_{4}$ yield (218 $\mathrm{cm}^{3} \mathrm{~g}^{-1}$ of VS) than Barley straw and B133 sorghum (average, $276 \mathrm{~cm}^{3} \mathrm{~g}^{-1}$ of VS). In treated substrates, Arundo achieved a similar $\mathrm{CH}_{4}$ yield with OAc.L and M+OAc.L (average, $272 \mathrm{~cm}^{3} \mathrm{~g}^{-1}$ of VS), and a further increase with $\mathrm{M}+\mathrm{OAc} . \mathrm{H}$ and OAc.H (330 and $354 \mathrm{~cm}^{3} \mathrm{~g}^{-1}$ of VS, respectively; Fig. 3). This corresponds to a 24,51 and $62 \%$ respective gain in $\mathrm{CH}_{4}$ yield vs. untreated Arundo. Pretreatments in Barley straw outlined a similar $\mathrm{CH}_{4}$ yield in OAc.L and $\mathrm{M}+\mathrm{OAc} . \mathrm{L}$ (average, $323 \mathrm{~cm}^{3} \mathrm{~g}^{-1}$ of VS), as in OAc.H and $\mathrm{M}+\mathrm{OAc} . \mathrm{H}$ (average, $380 \mathrm{~cm}^{3} \mathrm{~g}^{-1}$ of VS), determining a respective 20 and $41 \%$ increase. Conversely, in $\mathrm{B} 133$ sorghum a variable $\mathrm{CH}_{4}$ yield was obtained after pre-treatments: $307,335,373$ and $398 \mathrm{~cm}^{3} \mathrm{~g}^{-1}$ of VS at M+OAc.L, OAc.L, M+OAc.H and OAc.H, respectively. Hence, $\mathrm{CH}_{4}$ increase ranged between $8 \%(\mathrm{M}+\mathrm{OAc} . \mathrm{L})$ and $40 \%$ (OAc.H).

It is worth noting that B133 sorghum, a more biodegradable substrate, benefited less from pre-treatments than Barley straw and Arundo. Moreover, the addition of mineral acid to the organic acid determined a somewhat lower $\mathrm{CH}_{4}$ production, especially in $\mathrm{B} 133$ sorghum (Fig. 3). This may be due to competition between sulphate-reducing bacteria and methane producing Archea [30].

Fernandes et al. [11] studied the effect of maleic acid $\left(6 \mathrm{~kg} \mathrm{~m}^{-3}\right)$ pre-treatment $\left(150{ }^{\circ} \mathrm{C}\right.$ for $30 \mathrm{~min}$ ) on methane yield of three different substrates as hay, straw and bracken with different lignin content $\left(25,57\right.$ and $185 \mathrm{mg} \mathrm{g}^{-1}$ of VS, respectively). They found that methane yield of hay and straw was not enhanced after pretreatment, while a $57 \%$ increase (ca. $110 \mathrm{~cm}^{3} \mathrm{~g}^{-1}$ of VS) was shown in bracken. It appeared, therefore, that the effect of pretreatment was more profound in ligno-cellulosic biomass with a higher lignin content. This is consistent with the trend observed in our experiment: methane yield after pre-treatment augmented in parallel with the content of lignin in untreated substrate: 25,31 and $41 \% \mathrm{CH}_{4}$ yield increase with a lignin content of 198, 215 and $229 \mathrm{mg} \mathrm{g}^{-1}$ of VS, in the respective B133 sorghum, Barley straw and Arundo (Table 3).

In the previous experiment addressing mild alkaline pretreatments ( $\mathrm{NaOH}$ from 2 to $6 \mathrm{~kg} \mathrm{~m}^{-3}$ ) with the same three substrates [19], lower increases in $\mathrm{CH}_{4}$ yield were observed: up to 10 , 23 and 30\% in B133 sorghum, Barley straw and Arundo, respectively. Hence, maleic acid was shown a catalyst with a remarkable potential, in light of the recent findings on $\mathrm{AD}$ of ligno-cellulosic biomass.

\subsection{Changes in fibre composition and structure with pre- treatments}

During biodegradation, layers of lignin shield the two structural carbohydrates from enzymatic attack. Pre-treatments are devised to alter the ligno-cellulosic structure, even disrupt it, easing the bioconversion of ligno-cellulosic biomass. In this experiment, the reduction of the three structural components (Cell, H-cell and lignin) after pre-treatment varied in extent, depending on each specific substrate (Fig. 4). Conversely, the four acid combinations determined few, inconsistent variations between them. Arundo staged the strongest solubilisation of Cell and $\mathrm{H}$-cell as the effect of pre-treatments (from 18 to $21 \%$ and from 32 to $39 \%$ in the two respective compounds), compared to B133 sorghum (from 5 to $19 \%$ and from 4 to 16\%) and Barley straw (from 3 to $13 \%$ and from 25 to 
Table 4

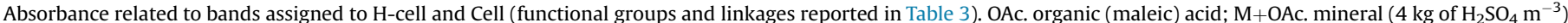

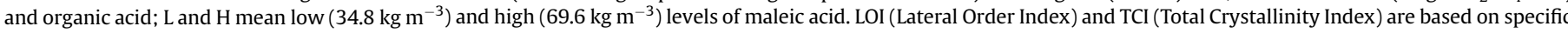
peak ratios. In brackets, standard deviation.

\begin{tabular}{|c|c|c|c|c|c|c|c|c|c|c|}
\hline \multirow[t]{2}{*}{ Substrate } & \multirow[t]{2}{*}{ Pre-treatments } & \multicolumn{7}{|c|}{ Wavenumbers $\left(\mathrm{cm}^{-1}\right)$} & \multirow[t]{2}{*}{ LOI } & \multirow[t]{2}{*}{$\mathrm{TCI}$} \\
\hline & & 2900 & 1720 & 1430 & 1375 & 1315 & 1158 & 898 & & \\
\hline \multirow[t]{5}{*}{ Arundo } & Untreated & 0.33 & 0.32 & 0.45 & 0.47 & 0.42 & 0.45 & 0.34 & $1.32(0.01)$ & $1.41(0.01)$ \\
\hline & OAc.L & 0.12 & 0.15 & 0.23 & 0.26 & 0.24 & 0.29 & 0.15 & $1.57(0.21)$ & $2.08(0.07)$ \\
\hline & OAc.H & 0.16 & 0.20 & 0.28 & 0.32 & 0.32 & 0.21 & 0.16 & $1.76(0.33)$ & $2.00(0.52)$ \\
\hline & $\mathrm{M}+\mathrm{OAc} . \mathrm{L}$ & 0.14 & 0.17 & 0.25 & 0.27 & 0.25 & 0.26 & 0.14 & $1.69(0.11)$ & $1.89(0.01)$ \\
\hline & $\mathrm{M}+\mathrm{OAc} . \mathrm{H}$ & 0.08 & 0.12 & 0.16 & 0.17 & 0.15 & 0.19 & 0.09 & $1.76(0.01)$ & $2.03(0.01)$ \\
\hline \multirow[t]{5}{*}{ Barley straw } & Untreated & 0.23 & 0.14 & 0.32 & 0.33 & 0.31 & 0.40 & 0.21 & $1.49(0.04)$ & $1.40(0.07)$ \\
\hline & OAc.L & 0.19 & 0.18 & 0.30 & 0.33 & 0.30 & 0.34 & 0.19 & $1.57(0.05)$ & $1.77(0.35)$ \\
\hline & OAc.H & 0.25 & 0.23 & 0.32 & 0.37 & 0.32 & 0.40 & 0.24 & $1.37(0.06)$ & $1.68(0.48)$ \\
\hline & $\mathrm{M}+\mathrm{OAc} . \mathrm{L}$ & 0.14 & 0.11 & 0.22 & 0.24 & 0.22 & 0.27 & 0.13 & $1.70(0.03)$ & $1.79(0.12)$ \\
\hline & $\mathrm{M}+\mathrm{OAc} . \mathrm{H}$ & 0.16 & 0.16 & 0.24 & 0.28 & 0.25 & 0.30 & 0.17 & $1.47(0.14)$ & $1.77(0.20)$ \\
\hline \multirow[t]{5}{*}{ B133 sorghum } & Untreated & 0.25 & 0.21 & 0.38 & 0.40 & 0.37 & 0.42 & 0.28 & $1.38(0.02)$ & $1.57(0.06)$ \\
\hline & OAc.L & 0.17 & 0.20 & 0.28 & 0.33 & 0.31 & 0.38 & 0.20 & $1.41(0.12)$ & $2.05(0.23)$ \\
\hline & OAc.H & 0.09 & 0.12 & 0.18 & 0.22 & 0.20 & 0.27 & 0.12 & $1.45(0.07)$ & $2.44(0.32)$ \\
\hline & $\mathrm{M}+\mathrm{OAc} . \mathrm{L}$ & 0.14 & 0.19 & 0.28 & 0.33 & 0.31 & 0.42 & 0.19 & $1.50(0.17)$ & $2.42(0.26)$ \\
\hline & $\mathrm{M}+\mathrm{OAc} . \mathrm{H}$ & 0.09 & 0.12 & 0.20 & 0.22 & 0.20 & 0.26 & 0.13 & $1.49(0.07)$ & $2.31(0.25)$ \\
\hline
\end{tabular}

33\%). Lastly, in the case of AIL the strongest reduction was observed in B133 sorghum (14\%, as average of the four pre-treatments), compared to Arundo (12\%) and Barley straw (9\%) (Fig. 4).

In the literature, maleic acid has already performed satisfactorily in H-cell hydrolysis $[13,31]$. H-cell reduction up to ca. $80 \%$ was obtained in wheat straw pre-treated with low concentration of maleic acid $\left(6 \mathrm{~kg} \mathrm{~m}^{-3}\right)$ combined with microwave heating $\left(170{ }^{\circ} \mathrm{C}\right.$ for $30 \mathrm{~min}$ ), while only a $12 \%$ Cell reduction was observed [32]. Likewise, Guo et al. [14] reported an $80 \% \mathrm{H}$-cell reduction in Miscanthus after pre-treatment $\left(170{ }^{\circ} \mathrm{C}\right.$ for $\left.6 \mathrm{~min}\right)$ with maleic and sulphuric acid at 61.5 and $7.4 \mathrm{~kg} \mathrm{~m}^{-3}$, respectively.

In addition, these authors demonstrated that maleic acid is mainly active on the easily hydrolysable fraction of H-cell. In fact, $\mathrm{H}$-cell in most ligno-cellulosic substrates may be present under two fractions, easy and hard to hydrolyze; the latter portion has been shown to account for $35 \%$ of the total [33]. Compared to the above referred works, our experiment exhibited up to $39 \% \mathrm{H}$-cell reduction, probably derived from the easily hydrolysable fraction. Beside its activity in the hydrolysis of $\mathrm{H}$-cell, maleic acid proved also effective in reducing Cell and lignin $(-19 \%$ and $-15 \%$ in the two respective components, as average of all substrates and pretreatments vs. untreated) (Fig. 4).

Changes in fibre composition are also supported by FTIR analysis, which has already been used to study the structural characteristic of ligno-cellulosic material [34]. Seven bands of particular relevance were analysed. Their spectra referring to untreated, organic and mineral plus organic acid at high concentration (OAc.H and $\mathrm{M}+\mathrm{OAc} . \mathrm{H}$, respectively) are displayed in Fig. 5; they are associated with the functional groups and compounds indicated in Table 2, according to the cited sources. In our experiment the bands assigned to $\mathrm{H}$-cell and Cell exhibited a decrease in absorbance after pre-treatment (Table 4), supporting a solubilisation of the two structural carbohydrates and a change in fibre structure [33]. TCI and LOI, indicating the overall degree of order of Cell and the mount of crystalline vs. amorphous Cell, respectively, were augmented after pre-treatment. This means that only amorphous Cell was likely solubilised (Table 4), although these changes had positive effects on substrate biodegradability, speeding the hydrolytic phase and enhancing final methane production.

\section{Conclusions}

Maleic acid, organic catalyst in the frame of a biomimetic approach to pre-treatments, was tested to improve methane yield from three ligno-cellulosic substrates. Remarkable physical and chemical changes of fibre structure occurred after pre-treatment, supporting the hypothesis of enhanced substrate degradation. This in turn determined increased methane yield, to an extent directly related to substrate recalcitrance: $+41,+31$ and $+24 \%$ in the respective Arundo, Barley straw and B133 sorghum (averages of the four pre-treatments).

Although a considerable increase in methane output was evidenced, appraisal of costs and benefits is mandatory, before the implementation of such treatments may be envisaged in full scale biogas plants.

\section{Acknowledgements}

Research carried out under the BIOSEA Project, funded by MiPAAF (Italy).

\section{References}

[1] G. Koçar, N. Civaș, An overview of biofuels from energy crops: current status and future prospects, Renew. Sust. Energy Rev. 28 (2013) 900-916.

[2] J. Valentine, J. Clifton-Brown, A. Hastings, P. Robson, G. Allison, P. Smith, Food vs. fuel: the use of land for lignocellulosic "next generation" energy crops that minimize competition with primary food production, GCB Bioenergy 4 (1) (2012) 1-19.

[3] C. Gallert, J. Winter, Bacterial metabolism in wastewater treatment systems in: H. Jördering, J. Witer (Eds.), Environmental Biotechnology - Concepts and Applications, Wiley-VCH, Weinheim, Germany, 2005, pp. 1-48.

[4] S.G. Pavlostathis, E. Giraldo-Gomez, Kinetics of anaerobic treatment, Water Sci. Technol. 24 (8) (1991) 35-59.

[5] N. Moiser, C. Myman, B. Dale, R. Elander, Y.Y. Lee, M. Holtzapple, et al., Features of promising technologies for pretreatment of lignocellulosic biomass, Bioresour. Technol. 96 (6) (2005) 673-686.

[6] M.J. Taherzadeh, K. Karimi, Acid-based hydrolysis processes for ethanol from lignocellulosic materials: a review, BioResources 2 (3) (2007) 472-499.

[7] G. Brodeur, E. Yau, K. Badal, J. Collier, K.B. Ramachandran, S. Ramakrishnan, Chemical and physicochemical pretreatment of lignocellulosic biomass: a review, Enzyme Res. 1-17 (2011) DOI. http://dx.doi.org/10.4061/2011/ 787532.

[8] J.W. Lee, T.W. Jeffries, Efficiencies of acid catalyst in the hydrolysis of lignocellulosic biomass over a range of combined severity factors, Bioresour Technol. 102 (10) (2011) 5884-5890.

[9] F. Monlau, E. Latrille, A.C. Da Costa, J.P. Steyer, H. Carrère, Enhancement of methane production from sunflower oil cakes by dilute acid pretreatment, Appl. Energy 102 (2013) 1105-1113.

[10] A.T.W.M. Hendriks, G. Zeeman, Pretreatments to enhance the digestibility of lignocellulosic biomass, Bioresour. Technol. 100 (1) (2009) 10-18.

[11] T.V. Fernandes, G.J. Klaase Bos, G. Zeeman, J.P.M. Sanders, J.B. van Lier, Effects of thermo-chemical pre-treatment on anaerobic biodegrability and hydrolysis of lignocellulosic biomass, Bioresour. Technol. 100 (9) (2009) 2575-2579.

[12] C. O'Reilly, C. Colleran, Effect of influent $\mathrm{COD} / \mathrm{SO}_{4}^{2-}$ ratios on mesophilic anaerobic reactor biomass populations: physico-chemical and microbiologica 
7

properties, FEMS Microbiol. Ecol. 56 (2006) 141-153.

[13] Y. Lu, N.S. Moiser, Biomimetic catalyst for hemicelluloses hydrolysis in corn stover, Biotechnol. Prog. 23 (1) (2007) 116-123.

[14] B. Guo, Y. Zhang, S.J. Ha, Y.S. Jin, E. Morgenroth, Combined biomimetic and organic acids hydrolysis of hemicelluloses in Miscanthus for bioethanol production, Bioresour. Technol. 110 (2012) 278-287.

[15] N.S. Moiser, A. Sarikaya, C.M. Ladisch, M.R. Ladisch, Characterization of dicarboxylic acids for cellulose hydrolysis, Biotechnol. Prog. 17 (3) (2001) 474-480.

[16] D. Scordia, S.L. Cosentino, T.W. Jeffries, Second generation bioethanol production from Saccharum spontaneum L. ssp. aegyptiacum (Wiild.) Hack, Bioresour. Technol. 101 (14) (2010) 5358-5365.

[17] D. Scordia, S.L. Cosentino, J.W. Lee, T.W. Jeffries, Dilute oxalic acid pretreatment for biorefining giant reed (Arundo donax L.), Biomass Bioenergy 35 (7) (2011) 3018-3024.

[18] D. Scordia, S.L. Cosentino, T.W. Jeffries, Effectiveness of dilute oxalic acid pretreatment of Miscanthus $\times$ giganteus biomass for ethanol production, Biomass Bioenergy. 59 (2013) 540-548.

[19] G. Di Girolamo, L. Bertin, L. Capecchi, C. Ciavatta, L. Barbanti, Mild alkaline pretreatments loosen fibre structure enhancing methane production from biomass crops and residues, Biomass Bioenergy. 71 (2014) 318-329.

[20] M.J. Metzger, R.G.H. Bunce, R.H.G. Jongman, C.A. Mücher, J.W. Watkins, A climatic stratification of the environment of Europe, Glob. Ecol. Biogeogr. 14 (2005) 549-563.

[21] I. Angelidaki, W. Sanders, Assessment of the anaerobic biodegradability of macropollutants, Rev. Environ. Sci. Biotechnol. 3 (2004) 117-129.

[22] I. Angelidaki, M. Alves, D. Bolzonella, L. Borzacconi, J.L. Campos, A.J. Guwy, et al., Defining the biomethane potential (BMP) of solid organic wastes and energy crops: a proposed protocol for batch assays, Water Sci. Technol. 59 (5) (2009) 927-934.

[23] C.Y. Liang, R.H. Marchessault, Infrared spectra of crystalline polysaccharides II. Native cellulose in the region from $640 \mathrm{~cm}^{-1}$ to $1700 \mathrm{~cm}^{-1}$, J. Polym. Sci. 30 (135) (1959) 269-278.

[24] S.G. Yang, J.H. Li, Z. Zheng, Z. Meng, Lignocellulosic structural changes of
Spartina alterniflora after anaerobic mono- and co-digestion, Int. Biodeterior. Biodegrad. 63 (5) (2009) 569-575.

[25] D. Stewart, H.M. Wilson, P.J. Hendra, I.M. Morrison, Fourier-Transform infrared and Raman Spectroscopic study of biochemical and chemical treatments of Oak wood (Quercus rubra) and Barley (Hordeum vulgare) straw, J. Agric. Food Chem. 43 (8) (1995) 2219-2225.

[26] M.L. Nelson, R.T. O'Connor, Relation of certain infrared band to cellulose crystallinity and crystal lattice type. Part II. A new infrared ratio for estimation of crystallinity in celluloses I and II, J. Appl. Polym. Sci. 8 (3) (1964) 1325-1341.

[27] F.G. Hurtubise, H. Krässig, Classification of fine structural characteristics in cellulose by infrared spectroscopy - use of potassium bromide pellet technique, Anal. Chem. 32 (1960) 177-181.

[28] Y.Q. Li, R.H. Zhang, X.Y. Liu, C. Chen, X. Xiao, L. Feng, et al., Evaluating methane production from anaerobic mono- and co-digestion of kitchen waste, corn stover, and chicken manure, Energy Fuel 27 (4) (2013) 2085-2091.

[29] C. Sambusiti, E. Ficara, F. Malpei, J.P. Steyer, H. Carrère, Effect of sodium hydroxide pretreatment on physical, chemical characteristics and methane production of five varieties of sorghum, Energy 55 (2013) 449-456.

[30] Y. Chen, J.J. Cheng, K.S. Creamer, Inhibition of anaerobic digestion process: a review, Bioresour. Technol. 99 (2008) 4044-4064.

[31] A.M.J. Kootstra, N.S. Moiser, E.L. Scott, H.H. Beeftink, J.P.M. Sanders, Differential effects of mineral and organic acids on the kinetics of arabinose degradation under lignocellulose pretreatment conditions, Biochem. Eng. J. 43 (1) (2009) 92-97.

[32] A.M.J. Kootstra, H.H. Beeftink, E.L. Scott, J.P.M. Sanders, Comparison of dilute mineral and organic acid pretreatment for enzymatic hydrolysis of wheat straw, Biochem. Eng. J. 46 (2) (2009) 126-131.

[33] S.E. Jacobsen, C.E. Wyman, Cellulose and hemicellulose hydrolysis models for application to current and novel pretreatment processes, Appl. Biochem. Biotechnol. 84 (2000) 81-96.

[34] A. Alemdar, M. Sain, Isolation and characterization of nanofibers from agricultural residues - wheat straw and soy hulls, Bioresour. Technol. 99 (2008) 1664-1671.
29

30

31

32

33

34

35

36

37
38

39

40

41

43

44

45

46

47

48

49

50

51

52

53

54

55

56 